\title{
Upaya Perpustakaan dalam Membangun Kolaborasi Riset Pustakawan di Universitas Sebelas Maret Surakarta
}

\author{
${ }^{1}$ Siti Nurkamilah, ${ }^{2}$ Wahid Nashihuddin \\ ${ }^{1}$ Prodi D3 Ilmu Perpustakaan - Universitas Sebelas Maret Surakarta \\ ${ }^{2}$ Lembaga Ilmu Pengetahuan Indonesia \\ ${ }^{1}$ E-mail: nurla.kamila156@gmail.com \\ ${ }^{2}$ E-mail: wahed87@gmail.com
}

\begin{abstract}
One of the ways to increase librarian's scientific publications is through research collaboration. Research collaboration is an intellectual activity that emphasizes the need for collaboration, communication, and the division of tasks of the research team in a research project. Librarians can carry out research collaborations with academics to enhance their role as research collaborators for institutions. The UNS Library has provided research information and research consulting services called "Klinik Pustaka Ilmiah". This research aims to identify the various efforts of the UNS Library in increasing librarian research publications, and building research collaborations of librarians with academics (lecturers and students). This study uses a qualitative approach, with data sources from interviews and documentation. The results showed that the UNS Library's "Klinik Pustaka Ilmiah" service really supports the collaborative research activities of academic librarians, and the library has made various efforts to increase research publications and librarian research collaborations. Researchers also suggest that the UNS Library be more active to encourage librarians in institutional research collaborations, and librarians also need to improve their research competence on an ongoing basis.
\end{abstract}

Keywords: Research Collaboration; Librarian Academic; Librarian Publication; Research Services; Research Competencies

\begin{abstract}
Abstrak
Salah satu untuk meningkatkan publikasi ilmiah pustakawan adalah melalui kolaborasi riset. Kolaborasi riset merupakan kegiatan intelektual yan menekankan perlunya kerjasama, komunikasi, dan pembagian tugas tim peneliti dalam suatu proyek penelitian. Pustakawan dapat melakukan kolaborasi riset dengan akademisi untuk meningkatkan perannya sebagai kolaborator riset lembaga. Perpustakaan UNS telah menyediakan layanan informasi riset dan konsultasi penelitian yang bernama "Klinik Pustaka
\end{abstract}

Tik Ilmeu : Jurnal Ilmu Perpustakaan dan Informasi

IAIN Curup | p-issn: 2580-3654; e-issn:2580-3662

DOI: $10.29240 /$ tik.v5i1.2279 
Ilmiah" Penelitian ini bertujuan untuk mengidentifikasi berbagai upaya Perpustakaan UNS dalam meningkatkan publikasi riset pustakawan, dan membangun kolaborasi riset pustakawan dengan akademisi (dosen dan mahasiswa). Penelitian ini menggunakan pendekatan kualitatif, dengan sumber data dari wawancara dan dokumentasi. Hasil penelitian menunjukkan bahwa layanan "Klinik Pustaka Ilmiah" Perpustakaan UNS sangat mendukung kegiatan kolaborasi riset pustakawan akademik, dan pihak perpustakaan telah melakukan berbagai upaya untuk meningkatkan publikasi riset dan kolaborasi riset pustakawan. Peneliti juga menyarankan agar Perpustakaan UNS lebih aktif lagi untuk menggiatkan pustakawannya dalam kolaborasi riset lembaga, dan pustakawan juga perlu meningkatkan kompetensi risetnya secara kesinambungan.

Kata Kunci: Kolaborasi Riset; Pustakawan Akademik; Publikasi Pustakawan; Layanan Penelitian; Kompetensi Riset

\section{A. PENDAHULUAN}

Perpustakaan merupakan jantungnya informasi universitas. Perpustakaan menjadi pusat repositori lembaga, yang menyimpan segala sumber informasi universitas, baik yang berupa koleksi umum, karya akademik, dan hasil penelitian. Perpustakaan akademik sangat mendukung terwujudnya tri dharma perguruan tinggi khususnya kegiatan penelitian. Pimpinan universitas perlu memperhatikan maka keberadaan perpustakaan khususnya untuk mendukung kegiatan penelitian (riset) lembaga, diataranya dengan melibatkan pustakawan dalam kegiatan riset lembaga dan memastikan ketersediaan sumberdaya informasi riset.

Pimpinan universitas dan perpustakaan dapat membangun bekerjasama melalui kegiatan komunikasi ilmiah dan kolaborasi riset akademik yang melibatkan pustakawan. Kerjasama ini dapat dituangkan dalam kebijakan tentang kewajiban sivitas akademik (dosen dan mahasiswa) untuk melibatkan perpustakaan dalam kegiatan penelitian, dan menjadikan pustakawan sebagai mitra riset mereka. Kebijakan tersebut sangat mendukung pustakawan untuk terlibat aktif dalam kegiatan penelitian lembaga, dan mendukung terwujudnya pusat penelitian di perpustakaan akademik. Kebijakan riset lembaga juga memotivasi pustakawan untuk meningkatkan perannya sebagai kolaborator riset yang ahli dalam kegiatan komunikasi ilmiah.

Sebagai kolaborator riset, pustakawan dapat membantu dosen dan mahasiswa secara maksimal dengan tugas dan peran yang seimbang dalam 
menyusun dan menyebarluaskan publikasi hasil penelitian. Selain itu, dapat meningkatkan kompetensinya dalam kegiatan komunikasi ilmiah, seperti pengelolaan jurnal lembaga dan pengelolaan data penelitian. Meskipun masih sebagai tenaga pendukung layanan riset lembaga yang bertugas membantu administrasi penelitian dan memberikan bantuan penelusuran informasi untuk referensi penelitian (Nashihuddin \& Trianggoro, 2018), pustakawan diharapkan dapat melakukan pendekatan akademik untuk berkolaborasi demi meningkatkan perannya sebagai tenaga strategis penelitian lembaga.

Menurut Pham \& Tanner (2014), kolaborasi merupakan aktivitas manusia untuk berbagai ide dan pengetahuan, membangun kekuatan dan sumber daya anggota dan organisasi untuk menyelesaikan masalah yang tidak mungkin diatasi secara individu. Kolaborasi antara pustakawan dan akademisi (dosen/mahasiswa) dapat dijadikan peralihan model pembelajaran yang tradisional di universitas, mengatasi tantangan yang ditimbulkan oleh dramatisasi pembelajaran, cara penyampaian, keragaman mahasiwa, dan perluasan sumberdaya Dalam kolaborasi ada aktivitas kerjasama antarindividu yang terjalin secara kemitraan, berdasarkan kesimbangan peran atau tugas untuk mencapai tujuan tertentu. Kolaborasi dapat berfungsi jika setiap anggota memahami tujuan satu sama lain dan tindakan yang diperlukan untuk mencapai tujuan tersebut. Melalui kolaborasi, pustakawan dapat bekerjasama dengan peneliti dan mendapatkan kredit publikasi. Kolaborasi riset juga dapat meningkatkan status profesi pustakawan, karena mampu berkontribusi dalam pengembangan sains dan teknologi bidang perpustakaan (Umar, 2000).

Kegiatan kolaborasi riset di perpustakaan berdampak pada peran dan tugas pustakawan. Perubahan peran dan tugas pustakawan terlihat dari adanya transisi tugas utama pustakawan, dari pengelolaan perpustakaan yang bersifat teknis dan administratif menjadi ke kegiatan pengembangan profesi dan sistem kepustakawanan. Salah satu tugas dari kegiatan tersebut adalah kemampuan pustakawan dalam melakukan pengkajian dan penelitian serta membuat karya tulis ilmiah bidang kepustakawanan. Tugas pengkajian dan penelitian pustakawan ini harus diimbangi dengan kompetensi atau kemampuan riset pustakawan, mulai dari mengetahui dan memahami akses informasi ilmiah yang luas, membuat dan menyusun karya tulis ilmiah bidang kepustakawanan, hingga memiliki ketrampilan berkomunikasi ilmiah yang baik dengan pengguna (Mukhlis \& Nashihuddin, 2020).

Kegiatan kolaborasi riset antara pustakawan dan akademisi juga telah dilakukan di beberapa universitas di berbagai negara. Pertama, di University of Toronto, Kanada. Fortin \& Mueller (2013) menjelaskan bahwa pustakawan membantu pemetaan Geographic Information System (GIS) 
dalam proyek The Don River Valley Historical Mapping Project (DVHMO). Pustakawan berkolaborasi dengan Mahasiswa Doktor Bidang Sejarah University of Guelph (Jennifer Bonnell) untuk meneliti tentang pemetaan sejarah kehidupan manusia di wilayah tertentu dengan memberdayakan sumber informasi perpustakaan. Kegiatan kolaborasi ini menghasilkan sebuah "peta set" sejarah geospasial berdasarkan data garis pantai, industri, dan kepemilikan tanah. Dalam proyek ini, pustakawan berperan sebagai seorang arsitek informasi dalam bidang GIS. Kedua, di University Cape Town (UCT), Afrika Selatan. DeJager et al. (2014) menjelaskan bahwa Pustakawan UCT melakukan kolaborasi dengan peneliti melalui program pengembangan kompetensi pustakawan yang bernama Research Library Consortium Academy (RLC Academy). Kegiatan ini disponsori oleh Carnegie Corporation of New York. Tujuan RLC Academy adalah untuk: (1) meningkatkan peran pustakawan secara signifikan dalam proses penciptaan pengetahuan; (2) meningkatkan karir dan pengetahuan pustakawan dalam proses penelitian; (3) mendorong kesadaran dan kemampuan pustakawan untuk mendukung penelitian di perpustakaan (asisten peneliti); (4) memotivasi pustakawan untuk berpartisipasi dalam perusahaan produksi pengetahuan di institusi mereka sendiri.

Ketiga, di University of Michigan Library (UML), Amerika Serikat. Brandenburg et al., (2017) menjelaskan bahwa pustakawan memiliki peran dalam pencarian dana bantuan dan sistematik review publikasi. Pustakawan UML berperan aktif sebagai pimpinan dalam proyek penelitian lembaga. Selain itu, mereka juga sebagai penyusun proposal kegiatan, mulai dari pencarian dana, menjalin komunikasi dengan seluruh stakeholder, hingga memantau perkembangan proyek penelitian secara berkala. Pustakawan membantu mencarikan sumber dana riset dari The University's Novel Funding Program "Mcubed" atau program MCubed Projects. Keempat, di Academic Resource Center (ARC) New York University (NYU) Shanghai \& Sino-American university di Cina. Bedi \& Walde (2017) menjelaskan bahwa ARC merupakan pusat sumber daya informasi bagi mahasiswa dalam mendapatkan layanan bimbingan belajar seperti kegiatan penulisan, ekonomi, dan sains. Pustakawan berkolaborasi dengan fakultas untuk merancang program pembelajaran pelatihan penulisan, untuk makalah tugas kuliah dan konferensi berdasarkan minat penulisan mahasiswa. Kegiatan tersebut didukung oleh Global Academic Fellows (GAF). Pustakawan berperan penting dalam kegiatan penelitian fakultas dan universitas. Mereka berperan penting dalam menyediakan pelayanan penelitian, mendukung penuh pengembangan keterampilan penelitian di fakultas, dan mencarikan pendanaan penelitian universitas. Pustakawan bertugas menyediakan data dan 
mengalisis data. Kegiatan kolaborasi penelitian menjadi investasi jangka panjang bagi pustakawan untuk mewujudkan the Canadian Academic Librarianship.

Pustakawan perlu mengantisipasi berbagai tantangan dalam berkolaborasi, diantaranya kesulitan dalam mencapai pemahaman yang sama setiap anggota untuk mencapai tujuan besar organisasi (Mcginn, 2004). Pustakawan akademik dapat bermitra dengan pusat bimbingan belajar untuk menciptakan pengalaman penelitian mahasiswa. Meskipun tidak semua proyek kolaborasi riset ini berjalan sukses, namun harus membangun hubungan kerjasama guna menciptakan peluang kolaborasi yang inovatif (Pun, 2016). Berbagai tantangan dalam kolaborasi riset di perpustakaan akademik menjadi preferensi bagi peneliti untuk mengkajinya di Perpustakaan Universitas Sebelas Maret Surakarta (UNS).

Perpustakaan UNS memiliki layanan informasi riset yang mendukung peningkatan peran pustakawan sebagai kolabotor riset akademik yaitu "Klinik Pustaka Ilmiah". Pustakawan yang bertugas di layanan tersebut harus memiliki kemampuan komunikasi ilmiah yang baik dan memiliki pengalaman yang luas dalam karya tulis ilmiah, baik skala nasional maupun internasional. Keberadaan layanan "Klinik Pustaka Ilmiah" dan upaya perpustakaan dalam meningkatan kegiatan kolaborasi riset pustakawan di UNS menjadi menarik untuk diteliti. Berdasarkan hal tersebut, penelitian ini fokus membahas dua hal, yaitu bagaimana upaya Perpustakaan UNS dalam meningkatkan publikasi riset pustakawan dan membangun kolaborasi riset akademik yang melibatkan pustakawan?

Penelitian menggunakan pendekatan kualitatif, untuk menganalisis berbagai permasalahan yang terjadi di lapangan. Creswell (2016) mengatakan bahwa penelitian kualitatif menjadi salah satu metode untuk mengeksplorasi dan memahami makna. Dengan pendekatan kualitatif, peneliti dapat memahami fenomena yang dialami oleh subjek penelitian secara holistik, dengan cara mendeskripsikan pada suatu konteks khusus dengan memanfaatkan berbagai metode alamiah. Pengumpulan data penelitian ini menggunakan teknik wawancara dan dokumentasi. Kegiatan wawancara dilakukan dengan informan penelitian, yaitu Kepala Perpustakaan UNS (1 orang), pustakawan UNS (3 orang) yang bertugas di layanan "Klinik Pustaka Ilmiah", dan pakar (3 orang) sebagai pengguna eksternal Perpustakaan UNS (berprofesi sebagai dosen dan pustakawan). Sementara teknik dokumentasi dilakukan melalui studi literatur yang relevan dan data publikasi Pustakawan UNS. Semua nama informan disamarkan dengan kode tertentu untuk menjaga privasi dan menghindari konflik penelitian. Kode informan 
penelitian ini yaitu KP (Kepala Perpustakaan); PW1,PW2,PW3 (Pustakawan); dan PK1,PK2,PK3 (Pakar). Data hasil wawancara kemudian dianalisis dengan teknik triangulasi model Miles dan Huberman (1992), yaitu reduksi data, display data, dan penarikan simpulan/verifikasi (Sugiyono, 2005). Hasil analisis data menjadi dasar penyusunan hasil dan pembahasan, serta kesimpulan penelitian ini.

\section{B. HASIL DAN PEMBAHASAN}

\section{Publikasi Riset Pustakawan Akademik}

Pustakawan akademik adalah pustakawan yang bekerja di perpustakaan akademik, yang dilatih untuk membantu orang menemukan informasi yang mereka butuhkan untuk mengajar, belajar dan riset (Kwanya, 2017). Salah satu peran penting pustakawan akademik adalah sebagai mitra atau partner dalam kegiatan riset di perguruan tinggi (Andayani, 2016). Menurut informan PK1, perpustakaan dapat berperan penting dalam kegiatan akademik di perguruan tinggi, misalnya kolaborasi dalam kegiatan publikasi ilmiah untuk mengurangi kesulitan menulis bagi dosen dan mahasiswa melalui peran pustakawan. Menurut Informan:

"Kolaborasi bukan berarti dosen, mahasiswa, dan pustakawan melakukan penelitian bersama, tetapi dapat berupa kesinambungan melalui individu dan bidang ilmu. Perpustakaan sebagai pendukung dalam penelitan".

Publikasi merupakan hal penting bagi akademisi untuk dapat memberitahukan kepada publik atas hasil penelitiannya, kemudian dapat dimanfaatkan oleh masyarakat. Publikasi mengajari kita untuk mengeluarkan pendapat, menghargai banyak pihak untuk saling berkontribusi dalam bentuk tulisan. Publikasi menjadi hal penting karena menjadi salah satu bukti utama orisinalitas dari rekam jejak peneliti. Keberhasilan penelitian dosen dan mahasiswa selama ini sangat didukung dengan pemenuhan kebutuhan informasi. Hal ini tentu tidak terpisahkan dari peran pustakawan dalam mengorganisir informasi yang disajikan. Menurut Informan PK3:

"Ada beberapa faktor yang menentukan keberhasilan kolaborasi di lingkungan universitas, hal tersebut dapat merujuk pada pendapat Mattessich et al. (2001), yaitu lingkungan kolaboratif yang mendukung; komitmen pimpinan untuk membangun hubungan timbal balik dan tujuan bersama; setiap anggota memiliki tanggung jawab bersama untuk pengembangan diri sesuai otoritas dan kapasitasnya masing-masing".

Dalam kegiatan riset, pustakawan dapat menjadi tenaga pendukung penelitian di perpustakaan ataupun menjadi kolaborator riset bagi akademisi. Menurut Informan PK2, keaktifan pustakawan dalam kegiatan riset akademik 
dapat dilihat dari kontribusinya dalam memberikan layanan pendukung riset mahasiswa dan dosen, seperti membantu pencarian informasi untuk bahan riset mereka.

"Perpustakaan merupakan 'palang pintu' pengelolaan informasi yang mampu menciptakan suatu kolaborasi, peneliti diharapkan ke perpustakaan dan pustakawan berperan membantu mencari informasi. Kolaborasi dalam hal ini terkait kegiatan teknis dalam penelitian seperti penggunaan Scopus, penyajian dan pencarian literatur. Pustakawan berperan sebagai fasilitator dalam diskusi terkait ide penelitian dari akademisi".

Keahlian pencarian informasi termasuk kompetensi literasi informasi pustakawan, yang terlihat dari kemampuannya dalam mengenali sumbersumber informasi, menelusur informasi, dan mengelola sitasi dan daftar pustaka karya ilmiah (Andayani, 2016). Sebagai ahli pencari informasi, pustakawan harus memiliki kepedulian yang tinggi terhadap pemanfaatan sumber-sumber informasi, yang dilakukan melalui komunikasi, pengecekan hasil penelusuran informasi, dan mengevaluasi dampak pemanfaatan informasi. Kepedulian tersebut menjadi salah satu bahan identifikasi perilaku informasi terhadap keahlian seseorang.

Keahlian perilaku informasi ini terlihat dari pengetahuan, pendidikan, pelatihan, pengalaman, tahap karir, dan lainnya dari pencari informasi (Robson \& Robinson, 2013). Misalnya pada perkenalan masalah penelitian, pustakawan melakukan pencarian informasi awal dengan menyelidiki berbagai batasan proyek riset, kerangka tematik, lingkup proyek, waktu yang diinginkan, dan persyaratan konten spesifik. Menanggapi tentang keahlian dalam pencarian informasi riset, Informan PK3 mengatakan bahwa:

"Seorang ahli informasi bidang riset, pustakawan tidak hanya dituntut mampu menyediakan sumber-sumber literatur dan mengelolanya untuk kepentingan riset, tetapi juga menganalisis informasi dalam literatur menjadi pengetahuan baru".

Pernyataan di atas senada dengan pendapat Choy (2007), bahwa ketika pustakawan dapat menciptakan pengetahuan baru, maka perannya semakin terlihat jelas dalam memberdayakan sumber daya informasi perpustakaan untuk kepentingan riset. Hal tersebut ditanggapi Informan PK3 bahwa:

"Sebagai produsen pengetahuan, pustakawan harus aktif melakukan riset dan menghasilkan publikasi ilmiah, dan kolaborasi riset menjadi upaya nyata pustakawan dalam memberikan layanan pendukung penelitian melalui perpustakaan".

Saat ini Pustakawan UNS mulai produktif membuat karya tulis ilmiah dan menggiatkan kolaborasi riset untuk meningkatkan kualitas 
terbitannya, baik dengan sesama pustakawan maupun dengan akademik (dosen dan mahasiswa). Berdasarkan hasil identifikasi karya tulis informan diketahui ada 9 (sembilan) orang (1 kepala perpustakaan dan 8 pustakawan) yang telah memiliki karya tulis/publikasi (Tabel 1)

Tabel 1. Daftar Karya Tulis Informan

\begin{tabular}{llc}
\hline No & \multicolumn{1}{c}{ Nama Penulis } & $\begin{array}{c}\text { Jumlah Karya } \\
\text { Tulis }\end{array}$ \\
\hline 1 & Muhammad Rohmadi (Kepala Perpustakaan UNS) & 3 Judul \\
\hline 2 & Widodo (Pustakawan UNS) & 11 Judul \\
\hline 3 & Harmawan (Pustakawan UNS) & 18 Judul \\
\hline 4 & Daryono (Pustakawan UNS) & 6 Judul \\
\hline 5 & Hardiningtyas (Pustakawan UNS) & 5 Judul \\
\hline 6 & Bambang Hermanto (Pustakawan UNS) & 7 Judul \\
\hline 7 & Riah Wiratningsih (Pustakawan UNS) & 10 Judul \\
\hline 8 & Sri Utari (Pustakawan UNS) & 4 Judul \\
\hline 9 & Tri Hardian (Pustakawan UNS) & 2 Judul
\end{tabular}

Sumber: https://library.uns.ac.id/librarians-paper/

Tabel 1 menunjukkan bahwa Pustakawan UNS telah memiliki karya tulis yang jumlahnya bervariasi, dan rata-rata mereka sudah memiliki semangat untuk meningkatkan publikasinya, baik karya tulis ilmiah maupun karya tulis populer. Menurut Informasi PW1:

"Menulis populer menjadi awal yang baik untuk meningkatkan data kritis penulis sehingga dapat memicu pustakawan untuk menulis ilmiah, yang bersumber dari hasil penelitian".

\section{Upaya Perpustakaan dalam Membangun Kolaborasi Riset Pustakawan}

Menurut Jacobs \& Berg (2013), di The Canadian Association of Research Libraries' (CARL) ada beberapa kegiatan pustakawan sebagai mitra riset pemustaka, diantaranya: (1) melakukan penelitian dan menghasilkan publikasi ilmiah; (2) berkompetisi dalam hibah penelitian; (3) mengikuti kegiatan seminar/konferensi sebagai presenter; pengembangan diri melalui asosiasi profesi bidang kepustakawanan; (5) berpartisipasi aktif dalam kegiatan pengajaran/pelatihan bidang kepustakawanan dan bidang lainnya untuk pengembangan profesi; (6) minat studi lanjut ke jenjang pendidikan formal yang lebih tinggi, baik program 
magister maupun doktoral; (7) aktif mengikuti kegiatan kemasyarakatan yang terkait program perpustakaan dan literasi informasi di masyarakat.

Perpustakaan UNS telah melakukan berbagai upaya untuk meningkatkan publikasi riset pustakawan di UNS dan membangun riset kolaboratif pustakawan dengan akademik, diantaranya sebagai berikut.

1) Meningkatkan budaya tulis dan riset bagi pustakawan di UNS, yang dimulai dari menulis artikel populer hingga artikel ilmiah. Penulisan artikel tersebut dapat dilakukan secara mandiri maupun kolaborasi, tergantung pada minat dan tujuan penulisan. Menanggapi hal tersebut, Kepala Perpustakaan UNS (Informan KP) selalu memotivasi pustakawannya untuk mengembangkan kualitas tulisan ilmiahnya ke tingkat nasional dan internasional.

"Kita tetap memotivasi para pustakawan di UNS untuk aktif menulis ilmiah keterbitan jurnal bereputasi nasional dan internasional, dan lebih baik lagi, artikel pustakawan dapat terindeks di Scopus. Ada salah satu pustakawan yang artikelnya sudah terindeks Scopus pada tahun 2018 yang berjudul "Library Clinic Services in Avoiding Transaction In The Predatory Journal". Hal tersebut dapat menjadi contoh yang bagus untuk pustakawan lain. Pustakawan yang bersangkutan kemudian membantu peningkatan kualitas tulisan pustakawan lain. Ia bisa sebagai mitra pustakawan lain, serta akademisi di lingkungan UNS dalam hal riset kolaboratif. Pustakawan yang sudah memiliki publikasi ilmiah internasional, diharapkan dapat menjadi mitra akademisi, dengan cara tersebut, peran pustakawan dalam bidang penelitian terlihat nyata".

2) Mereview peraturan terkait peran perpustakaan dan pustakawan dalam kegiatan riset universitas. Pustakawan di UNS dapat merujuk pada peraturan Rektor Universitas Sebelas Maret No.585/Un27/Hk/2015 tentang Pengelolaan dan Penyelenggaraan Pendidikan Program Magister dan Program Doktor, khusunya pada Pasal 10 ayat (6) dan ayat (7).

"Ayat 6 menyebutkan "salah satu komponen capaian pembelajaran untuk lulusan program magister, yaitu wajib memiliki keterampilan umum menghasilkan karya ilmiah dalam bentuk tesis dan 1 (satu) makalah yang telah diterbitkan/diterima pada jurnal llmiah nasional terakreditasi atau 1 (satu) makalah yang telah dipresentasikan dalam seminar internasional dan diterbitkan dalam bentuk prosiding internasional terindeks Scopus"; dan Ayat 7 menyebutkan "Salah satu komponen capaian pembelajaran untuk lulusan program doktor, yaitu wajib memiliki keterampilan umum menghasilkan karya ilmiah dalam bentuk disertasi dan 1 (satu) makalah yang telah diterbitkan/diterima di jurnal internasional bereputasi (terindeks di Scopus atau yang setara, serta tidak dikategorikan sebagai jurnal predator) atau 2 
(dua) makalah yang telah dipresentasikan dalam semtnar internasional dan diterbitkan dalam bentuk prosiding Internasional terindeks Scopus".

Ketentuan publikasi ilmiah bagi mahasiswa magister dan doktoral tentunya menjadi peluang bagi pustakawan untuk terlibat aktif dalam penyediaan sumber-sumber referensi untuk riset akademik. Pustakawan dapat menawarkan kolaborasi untuk penyusunan publikasi ilmiah turunan dari tesis dan/atau disertasi. Dalam hal ini, pustakawan dapat membahas lebih mendalam tentang sebagian topik dari hasil tesis dan/atau disertasi dengan meng-update data terbarunya untuk artikel jurnal atau makalah konferensi (prosiding). Dalam kolaborasi penulisan, posisi pustakawan sebagai penulis kedua (co-authorship) yang bertugas menulis kembali gagasan dari penulis pertama berdasarkan template publikasi yang akan dituju. Cara lain adalah pustakawan membuka jasa konsultasi untuk penulisan ilmiah bagi mahasiswa magister dan doktoral, dan mendampingi mereka hingga submit publikasi yang dituju, baik nasional maupun internasional.

3) Mengoptimalkan layanan "Klinik Pustaka Ilmiah" di perpustakaan. Terkait peraturan di atas, Perpustakaan UNS menyediakan jasa konsultasi penulisan bagi mahasiswa dengan nama "Klinik Pustaka Ilmiah". Dalam layanan tersebut, pustakawan yang memiliki pengalaman menulis artikel Internasional bertugas mendampingi mahasiswa pascasarjana yang akan men-submit artikelnya ke jurnal atau konferensi internasional. Hal tersebut disampaikan oleh Kepala Perpustakaan UNS $(\mathrm{KP})$ :

\begin{abstract}
"Klinik Pustaka Ilmiah dibangun untuk mengoptimalkan fungsi perpustakaan sebagai pusat belajar, informasi, dan literasi. perpustakaan sebagai pusat sumber literasi. Layanan ini diharapkan dapat menarik dosen dan mahasiswa yang akan menulis dan meneliti untuk giat datang ke perpustakaan. Pustakawan yang bertugas di Klinik Pustaka Ilmiah akan mendampingi mahasiswa dan dosen dalam publikasi ilmiah, hingga dicarikan referensi terbitan internasional yang akan menjadi tujuan submit artikel".
\end{abstract}

Pernyataan informan KP di atas menjelaskan bahwa "Klinik Pustaka Ilmiah" bertujuan untuk menarik minat dosen untuk berkunjung ke Perpustakaan UNS. Dosen yang datang ke layanan tersebut diharapkan dapat berkolaborasi dengan pustakawan UNS untuk menulis dan meneliti bersama. Dosen perlu memanfaatkan informasi riset di perpustakaan, untuk menunjang kualitas pendidikan tinggi. Menurut Informan KP:

"Sangat ironis jika dosen sebagai produsen riset universitas jarang berkunjung ke perpustakaan, termasuk ketika memberikan tugas makalah/artikel", mereka juga jarang mendampingi mahasiswa ke 
perpustakaan. Klinik Pustaka Ilmiah menjadi kesempatan bagi dosen, mahasiswa, dan pustakawan untuk menjalin kerjasama penelitian. Bagi mahasiswa yang sedang mengerjakan tugas kuliah (makalah) dan menyusun tugas akhir (skripsi, tesis, disertasi) namun merasa kesulitan dalam mengakses dan mencari sumber-sumber referensi (e-journal dan e-book), dapat menghubungi pustakawan untuk mendapatkan bantuan penelusuran informasi".

Menanggapi pernyataan Informan KP, pustakawan yang bertugas di layanan Klinik Pustaka Ilmiah (Informan PW1, PW2, PW3) mengatakan bahwa:

"Hal di atas adalah benar, mahasiswa dapat memanfaatkan secara optimal layanan tersebut untuk pembuatan makalah dan artikel lainnya. Apabila mengalami kesulitan dalam pencarian referensi penelitian, pustakawan akan siap membantu dan mendampingi mahasiswa dalam peningkatan kualitas artikel. Kami selalu menginformasikan ke mahasiswa untuk banyak membaca artikel jurnal internasional, agar tulisannya bagus. Bagi mahasiswa yang menginginkan bantuan pendampingan penulisan artikel jurnal, kami siap membantu, mulai dari mencarikan template naskah hingga check plagiarism dengan turnitin, hingga pemilihan jurnal yang bereputasi internasional, yang bukan jurnal predator".

Mengacu pernyataan informan di atas, pustakawan yang bertugas di "Klinik Pustaka Ilmiah" minimal memiliki kompetensi terkait penelusuran informasi, penyediaan data riset, dan menyeleksi jurnal berkualitas.

4) Meningkatkan peran pustakawan dalam kegiatan penelitian akademik. Bagi pustakawan di UNS, penelitian dapat meningkatkan peran mereka dalam kegiatan penelitian lembaga. Klinik Pustaka Ilmiah dapat dimanfaatkan pustakawan untuk meningkatkan perannya dalam mendukung kegiatan penelitian akademik, baik mahasiswa maupun dosen. Peran pustakawan ini untuk meningkatkan kontribusinya dalam kegiatan riset akademik yang berbasis kemitraan. Hal tersebut disampaikan Informan PW2:

"Peran pustakawan terlihat ketika dirinya sebagai supporting system dalam kegiatan riset akademik, pustakawan aktif memberikan ide dan pemikiran baru kepada akademisi untuk membuat kajian/riset yang mutakhir, berdasarkan isuisu yang berkembang di masyarakat. Ketika peran pustakawan semakin besar dalam kegiatan riset lembaga, tak menutup kemungkinan ia dapat merumuskan kebijakan perpustakaan dalam penguatan riset akademik, untuk membangun kolaborasi riset akademik yang kondusif dan berbasis kemitraan" 
5) Meningkatkan kompetensi riset pustakawan. Kompetensi riset diperlukan juga untuk meningkatkan produktivitas menulis ilmiah pustakawan dalam riset kolaboratif lembaga. Berg \& Banks (2016) menjelaskan perlu ada minat yang kuat dan kompetensi pustakawan yang memadai untuk melaksanakan penelitian, sehingga memunculkan sinergitas dari kedua belah pihak, baik dari pustakawan maupun dari pemustaka (akademisi). Di UNS, publikasi ilmiah menjadi syarat wajib pustakawan dan akademisi untuk kenaikan pangkat dan jabatan, dan bagi mahasiswa pascasarjana sebagai syarat kelulusan akademik (wisuda). Hal tersebut, tentunya perlu diperhatikan oleh pustakawan dan sivitas akademik untuk senantiasa meningkatkan kontribusinya dalam kegiatan riset untuk pengembangan pengetahuan dan kreativitas akademik berbasis riset. Bagi dosen di lingkungan UNS dapat berkolaborasi dengan pustakawan untuk meningkatkan produktivitas publikasi ilmiahnya. Kompetensi riset ini diperlukan pustakawan untuk menjadi seorang konsultan pengetahuan. Sebagaimana dikatakan Informan KP:

"Sebagai konsultan pengetahuan, pustakawan harus memiliki kompetensi riset, khususnya pustakawan yang bertugas di layanan Klinik Pustaka Ilmiah. Bagi pustakawan yang sudah memiliki kompetensi risat diharapkan dapat mentransfer ilmunya ke pustakawan lain, sebagai bekal mereka menjadi kolaborator riset lembaga".

Terkait dengan kompetensi riset pustakawan, Informan PK3 menjelaskan bahwa:

"Kompetensi menulis dan meneliti, serta membuat publikasi ilmiah merupakan kompetensi khusus pustakawan. Kompetensi khusus merupakan kompetensi tingkat lanjut yang bersifat spesifik, dalam konteks ini adalah kemampuan pustakawan dalam kegiatan kolaborasi riset akademik yang menghasilkan karya tulis ilmiah. Karya tulis ilmiah adalah bentuk atau gaya penulisan yang bersifat ilmiah, umumnya bertujuan untuk memberi informasi berisi ide-ide dan argumentasi yang dapat dipertanggungjawabkan, berasal dari penelitian, tinjauan kepustakaan atau kegiatan ilmiah lainnya sebagaimana yang dinyatakan dalam dokumen SKKNI tahun 2012".

Menanggapi masalah kompetensi riset, Informan PW1 menjelaskan kondisi di lapangan bahwa:

"Sejauh ini belum banyak yang mengetahui adanya Klinik Pustaka Ilmiah, dan mungkin dari komitmen pustakawan untuk merubah konsep lamanya menjadi sosok pustakawan saat ini yang seperti apa? misalnya, kemampuan TI-nya perlu dikembangkan, berpartisipasi aktif dalam kegiatan/pertemuan ilmiah, dsb." 
Menurutnya, kompetensi pustakawan di UNS seharusnya ditingkatkan secara kesinambungan, agar dapat menyesuaikan perkembangan iptek, mengikuti perilaku pengguna dalam penelusuran informasi, dan memenuhi kebutuhan informasi pemustaka yang semakin kompleks. Berbagai kompetensi di atas diperlukan untuk mendukung tugas pustakawan sebagai mitra riset peneliti di lembaganya. Pustakawan juga diharapkan mampu mengembangkan potensi dirinya bukan hanya sebagai pelayan informasi, namun sebagai pencipta informasi dan pengetahuan.

6) Menyinergikan peta riset universitas dengan layanan perpustakaan. Hal ini dikatakan Informan PK2 bahwa budaya epistemik riset dapat menyinergikan kegiatan riset akademik dengan program layanan di perpustakaan. Sinergi riset akademik dapat dimulai dari kegiatan identifikasi kebutuhan informasi dan sumber daya riset di perpustakaan. Kebutuhan informasi dapat dimulai dari mengenali karakteristik pengguna, mengkaji kebutuhan informasi pengguna dan mendorong untuk memanfaatkan fasilitas yang ada di perpustakaan (Nugrohoadhi, 2017). Hal ini dikatakan Informan PK2:

“Untuk membangun budaya 'epistemik' riset universitas perlu dibuatkan peta riset yang terintegrasi dengan program layanan perpustakaan. Peta riset ini menginformasikan tentang pelaksanaan riset kolaboratif akademik dengan perpustakaan".

Hal-hal yang diinformasikan di peta riset ini, antara lain dukungan universitas dalam riset kolaboratif di perpustakaan; penguatan jaringan dan kerjasama penelitian dengan pihak eksternal (termasuk sumber alternatif pembiayaan penelitian); pengembangan dan tata kelola informasi, sistem, sarana dan prasarana penelitian; penguatan peran pustakawan sebagai subjek spesialis yang ahli dalam bidang riset.

\section{KESIMPULAN}

Perpustakaan merupakan institusi penting yang berperan dalam penyediaan informasi riset di universitas. Perpustakaan UNS sebagai mitra strategis universitas mengambil peran penting dalam kegiatan riset lembaga. Salah satu upaya perpustakaan untuk meningkatkan perannya sebagai mitra riset universitas adalah menguatkan kontribusi pustakawan UNS dalam kegiatan riset kolaboratif lembaga. Kolaborasi riset antara pustakawan dan akademisi dapat meningkatkan aksesiblitas informasi perpustakaan, dan menarik minat dosen dan mahasiswa untuk berkolaborasi dengan pustakawan. Berdasarkan pembahasan di atas, terlihat bahwa Perpustakaan UNS perlu membangun budaya riset kolaboratif untuk meningkatkan 
publikasi riset pustakawan, serta menyiapkan sarana yang memadai untuk mendukung peran pustakawan sebagai kolaborator riset yang dapat menghasilkan pengetahuan baru. Perpustakaan UNS telah menyiapkan layanan "Klinik Pustaka Ilmiah" untuk menfasilitasi kegiatan kolaborasi riset pustakawan. Pustakawan dapat mengoptimalkan layanan tersebut untuk membantu pemustaka dalam mencari informasi riset. Untuk mendukung layanan "Klinik Pustaka Ilmiah", pustakawan UNS perlu menyiapkan kompetensi riset, baik melalui kegiatan pendampingan penelitian, pertemuan ilmiah (seminar/konferensi), pengajaran/pelatihan, dsb. Perpustakaan UNS juga perlu melihat kembali peta riset universitas sehingga dapat bersinergi dengan program layanan riset perpustakaan. Peta riset tersebut menjadi dasar perpustakaan untuk memberikan layanan penelitian kepada sivitas akademik dan menguatkan peran pustakawan sebagai kolaborator riset lembaga. Peneliti juga menyarankan agar Perpustakaan UNS perlu melibatkan pustakawannya dalam kegiatan riset lembaga, dengan cara berkoordinasi kembali dengan pihak universitas (dalam hal ini Lembaga Penelitian dan Pengabdian Masyarakat UNS), dan Pustakawan UNS juga meningkatkan kompetensi riset dan komunukasi ilmiahnya secara kesinambungan.

\section{DAFTAR RUJUKAN}

Andayani, U. (2016). Pustakawan akademik sebagai mitra riset di perguruan tinggi. Jurnal Al-Maktabah, 15(1).

Bedi, S., \& Walde, C. (2017). Transforming roles: Canadian Academic Librarians embedded in faculty research projects. College \& Research Libraries, 78(3), 314-327.

Berg, S. A., \& Banks, M. (2016). Beyond competencies: Naming librarians' capacity for research. The Journal of Academic Librarianship, 42(4), $469-471$.

Brandenburg, M. D., Cordell, S. A., Joque, J., MacEachern, M. P., \& Song, J. (2017). Interdisciplinary collaboration: Librarian involvement in grant projects. College \& Research Libraries, 78(3), 272-282.

Choy, C. F. (2007). Libraries and librarians: What next? Library Management, 28(3), 112-124.

Creswell, J. W. (2016). Research design: Pendekatan metode kualitatif, kuantitatif, dan campuran. Pustaka Pelajar.

DeJager, K., Nassimbeni, M., \& Crowster, N. (2014). Developing a new 
librarian: Library research support in South Africa. Information Development, 32(3), 285-292.

Fortin, M., \& Mueller, J. (2013). The Library as research partner and data creator: The don valley historical mapping project. Journal of Map \& Geography Libraries: Advances in Geospatial Information, Collections \& Archives, 9(1-2), 157-174.

Jacobs, H. L. M., \& Berg, S. A. (2013). By librarians, for librarians: Building a strengths-based institute to develop librarians' research culture in Canadian academic libraries. The Journal of Academic Librarianship, 39(1), 227-231. https://doi.org/https://doi.org/http://dx.doi.org/10.1016/j.acalib.2013.02. 003

Kwanya, T. (2017). Collaboration between academic librarians in Kenya: A social network analysis. Paper of The Conference: Kenya Library Association International Conference. https://www.researchgate.net/publication/318850595_Collaboration_bet ween_academic_librarians_in_Kenya_a_social_network_analysis

Mattessich, P., Murray-Close, M., \& Monsey, B. R. (2001). Collaboration: What makes it work (2nd Ed.). Wilder Publishing Centre.

Mcginn, N. F. (2004). International cooperation in comparative education research: The six nation education research project. In N. F. Mcginn (Ed.), Learning Through Collaborative Research (p. 2). RoutledgeFalmer.

Mukhlis, M., \& Nashihuddin, W. (2020). Komunikasi ilmiah: Konsep dan praktik penerapannya dalam konteks kepustakawanan. ISIPII Press.

Nashihuddin, W., \& Trianggoro, C. (2018). Research collaboration sebagai upaya pustakawan menjadi produsen pengetahuan. Makalah Konferensi Perpustakaan Digital Indonesia.

Nugrohoadhi, A. (2017). Pemanfaatan publikasi ilmiah di perguruan tinggi. Pustakaloka, 9(2), 66-82.

Pham, H. T., \& Tanner, K. (2014). Collaboration between academics and librarians: A literature review and framework for analysis. Library Review, 63(1-2).

Pun, R. (2016). The library and the academic resource center: Building and 
16 | Siti Nurkamilah, dkk: Upaya Perpustakaan...

supporting programs, services and resources collaboratively at a new university. Digital Library Perspectives, 32(1), 31-40.

Robson, A., \& Robinson, L. (2013). Building on models of information behaviour: Linking information seeking and communication. Journal of Documentation, 69(2), 169-193.

Sugiyono, S. (2005). Memahami penelitian kualitatif. Alfabeta.

Umar, A. (2000). Kerjasama peneliti dan pustakawan: Upaya memberdayakan pustakawan dalam kegiatan penelitian di IAIN Jakarta. AL-MAKTABAH: Jurnal Komunikasi Dan Informasi Perpustakaan, 2(1), 10-19. 